\title{
Ethnologies
}

\section{Women as Unseen Characters: Male Ritual in Papua New \\ Guinea. By Pascale Bonnemère. (Philadelphia, University of \\ Pennsylvania Press, 2004. Pp. 200, ISBN 0-8122-3789-7)}

\section{Bridget E. Cauthery}

Volume 31, numéro 2, 2010

Figures noires

Black Images

URI : https://id.erudit.org/iderudit/039379ar

DOI : https://doi.org/10.7202/039379ar

Aller au sommaire du numéro

\section{Éditeur(s)}

Association Canadienne d'Ethnologie et de Folklore

ISSN

1481-5974 (imprimé)

1708-0401 (numérique)

Découvrir la revue

Citer ce compte rendu

Cauthery, B. (2010). Compte rendu de [Women as Unseen Characters: Male Ritual in Papua New Guinea. By Pascale Bonnemère. (Philadelphia, University of Pennsylvania Press, 2004. Pp. 200, ISBN 0-8122-3789-7)]. Ethnologies, 31(2),

335-337. https://doi.org/10.7202/039379ar d'utilisation que vous pouvez consulter en ligne. 
responsibility Miyakawa seems to feel towards her subjects is inspiring, and neatly reflects her subjects' values of peace and knowledge.

Dana Baitz

York University

Women as Unseen Characters: Male Ritual in Papua New Guinea. By Pascale Bonnemère. (Philadelphia, University of Pennsylvania Press, 2004. Pp. 200, ISBN 0-8122-3789-7)

The societies of Melanesia and their pervasive gender polarizations have occupied a prominent place within anthropological research. Women as Unseen Characters is an anthology of nine essays by male and female anthropologists with special interest in the ritual practices of the peoples of Papua New Guinea. This includes analysis and comparison of the initiation rites, ceremonies, secret societies, social life, customs and attitudes of the Gebusi, Duna, Ipili, Enga, Hagen, Sambia, Ankave, Kamea and Ömie peoples. There is particular emphasis on the Eastern Highland Provinces where a history of violent conflict between groups has produced exaggerated gender divisions. The essays were selected for their dual focus on the participation of women and the concern that such participation has been overlooked in previous scholarship.

Women as Unseen Characters grew out of "collective reflection" expressed at a special symposium convened by Pascale Bonnemère at the Association for Social Anthropology in Oceania's annual meeting in 1998. Scholars came together to discuss the absence of critical discussions of women's roles in ethnographic studies of male-centred ritual in Papua New Guinea. Bonnemère, a fellow at the French National Center for Scientific Research (CNRS), was drawn to this particular focus after her experiences in the field among the Ankave in the New Guinea Highlands. There she found that her own observations of malecentred rituals contradicted what she had read concerning practices of the region. Citing Read (1952), Herdt (1987) and Langness (1999), Bonnemère describes how these studies equate the exclusion of women from the ritual space to the exclusion of women from the ritual process. 
Based on what she witnessed in the field, Bonnemère broadened the commonly held conception of Ankave ritual space to include the special structures on the edge of the village where initiates' mothers were secluded and expected to undertake certain tasks and observances while their male kin were secluded in the forest. Perceiving reciprocity between male and female ritual behaviour in the Ankave example that was previously unreported led Bonnemère to question whether other ethnographic research on male ritual practices in Papua New Guinea were likewise flawed.

Drawing on themes discussed by Arve Sørum (1980) and Annette Weiner (1982) in their work on the male rites of the Bedamini and Bimin-Kuskusmin respectively, Bonnemère is critical that the subject of female participation in male rituals and the related issues of Euroand ethnocentrism as they impact gender have not been explored more rigorously. As a result, Bonnemère and fellow contributors seek both to provide ethnographic evidence that confirms the presence and influence of women on male ritual process and to address why women's participation in male ritual has remained unacknowledged by anthropologists working in Melanesia. Such work, Bonnemère believes, remedies an "undeniable gap" in the ethnographic literature on New Guinea and in feminist studies.

Following the introduction where Bonnemère presents a thorough literature review, contextualizes prevalent issues within the field and draws analogies to similar gaps in ethnographic work on other aboriginal groups, contributors enter into discussions centred on initiation rites, bachelor cults and female spirit cults - the three main types of male ritual. While some essays concentrate on the practices of one particular group, others look at how certain practices compare between groups linked by language and/or geography. Bonnemère, Sandra Bamford, Pierre Lemonnier, Marta Rohatynski and Bruce M. Knauft discuss the participation of "flesh and blood" women in initiation rites; Aletta Biersack and Polly Wiessner write about bachelor cults within the Ipili and their eastern neighbours, the Enga, with regard to participants' relationships with a female spirit who will protect them from dangers implicit in sexual relations with their future wives; Andrew Strathern and Pamela J. Stewart focus on female spiritual cults where contact between male participants and a female spirit and/or objects symbolic of femaleness will restore lost fertility to both land and humans; and Gilbert Herdt considers the inclusion of both real women and spiritual female figures in the initiation rituals of the Sambia. 
In terms of methodological approaches, Bonnemère and Lemonnier, for example, are able to draw from fieldwork conducted in the 1990s among groups who, because of their remoteness, continue to practice initiation rites with little interference from either church or government. In contrast, Rohatynski writing on the Ömie, had to rely on the recollections of elders within the community to reconstruct initiation rites, since such practices were abandoned in the 1940s. In theorizing their work, Strathern and Stewart recognize a "collaborative model" that functions in opposition to what they perceive as a "male exclusivity model." In a collaborative model, any intervention by women in ritual practice gives equal importance to the participation of men and women without measuring degrees of presence. Knauft's analysis centres on the recognition of shifting discourses with regard to the construction of personhood, where until the 1980s, personhood took as its premise the creation of individuals independently of their relationships to other adults. Working within this framework, Knauft perceives that it is therefore not surprising that male-centred rituals were seen to involve, affect and benefit only men.

It is interesting to note that while Bonnemère and the other contributors find fault with the way anthropologists have traditionally approached and analysed male rituals in Papua New Guinea, such criticism does not by default question commonly held beliefs that groups practicing male-centred rituals are characterized by antagonistic gender relations and/or pronounced gender biases. Focussing attention on women's roles does not negate the male bias that exists within the groups under study but demonstrates how women contribute to and exist within this biased sphere. The volume also demonstrates the importance of revisiting and questioning the findings of pioneering studies when traditional ways of life are rapidly disappearing.

At a crossroads between anthropology and feminist studies, though perhaps more pertinent to the former, Women as Unseen Characters represents a new and important direction in revisionist ethnography. While individual essays would make compelling and insightful reading for an introductory course in ethnographic research, appreciating the volume as a whole and its particular contributions to current research on Melanesia is more suited to specialists within the field. 